\title{
Biodiversity and the African Savanna: Problems of Definition and Interpretation
}

\section{Michael O'Neal Campbell}

Environmental Scientist, Lake head University, Ontario, Canada

\begin{abstract}
This article examines the various theoretical frameworks and paradigm tools in ecological methods that have been developed to analyze the structure of the African savanna. These are based on the new disequilibrium ecology paradigm, (in contrast to the classical ecology paradigm), which sees the savanna as in continual flux rather than sable equilibrium, and attempt to answer questions concerning socio-environmental relations and environmental change. This topic is crucial to the study of biodiversity and endangered species, as the savanna may be intermediate between forest and desert, and may be the habitat of numerous forest and desert species. The savanna is an ecosystem in its own right and also results from the processes of deforestation, desertification and extinction. The results of the review support the hypothesis that the complexity of the African savanna precludes the usage of classical equilibrium ecology, and the integrated research methods provide a useful basis for the advancement of biodiversity studies for the practical applications of comparative evaluation, measurement of multidirectional change and long-term assessment
\end{abstract}

Keywords: Africa; Biodiversity biogeography; Disequilibrium; Ecology; Savanna

\section{Introduction}

Forastudyoftherelationshipbetweenlanduseand phytogeographical change within a savanna context, from a disequilibrium perspective, the main theme is socio-environmental co evolution. Three main issues must be considered to examine the dynamics and sources of trends in socio-environmental relations. The natural environment, subject to dynamic change, may be interpreted, using the tenets of the disequilibrium school of ecology (which holds that non-linear change and chaotic fluctuations due to socio-environmental interactions offer a more incisive analysis than linear, mechanistic approaches). Human society, also a dynamic and multifaceted phenomenon, may be understood as the interaction of human agency and social structures, in relation to land use. The integration of socio-environmental relationships that are an intrinsic part of both these entities must be the center of our analysis. To analyze and explain adequately such multifaceted issues, with recourse to literature of an often specialized and discipline-conscious nature, requires the acceptance of paradoxes and differing approaches to similar problems. Therefore, the various threads of argument are synthesized to portray the multiplicity and complexity of phytogeographical change. Firstly, various definitions of savanna are considered, as well as the theoretical frameworks developed to describe and analyze savanna ecosystems. This is followed by the analysis of applications of the theoretical frameworks to examples from the African savanna.

\section{Definitions of Savanna}

The environmental context most relevant to the ideas presented above is the tropical savanna. However, there is no definitive agreement about what constitutes savanna vegetation [1], because savannas are highly heterogeneous. Notably, The "word savanna has had an ambiguous career since it entered the English language in the 16th century" [2 - 6]. While "the central concept - a tropical mixed tree-grass community- is widely accepted". The "delimitation of the boundaries has always been a problem" [ 7 ]. Therefore, a sensible position is that the savanna represents a "continuum of vegetation types which have trees and grasses as their main constituents", while "acknowledging that at the extremes, the distinction between savannas and woodlands is unavoidably arbitrary" [ 7 ].
To attempt a concise definition, savanna is a "tropical vegetation type in which ecological processes, such as primary production, hydrology and nutrient cycling, are strongly influenced by both woody plants and grasses, and only weakly influenced by plants of other growth forms" [ 7 ]. This definition is based on that which emerged from the International Responses of Savanna to Stresses and Disturbance (RSSD) Program. To enlarge on this, savanna "designates tropical grassland with scattered trees" and is the "most common tropical landscape unit" [ 2, 8 ] . They are "delineated both structurally (specifying a wood/ grass composition) and climatically (seasonality of water availability)" [ 9 ], and "the structure and dynamics of savanna vegetation is generally expressed as the balance between trees and grasses, and more easily by tree density and distribution" [ 10 ].

A relevant is whether the vegetation type referred to as tropical thicket is a type of savanna, as this is a "vegetation formation which does not fit comfortably into the savanna definition" [11 ]. Tropical thicket is described as vegetation dominated by multi-stemmed woody plants (of course some multi-stemmed woody plants owe their form to cutting for firewood), and in some cases with no grasses, supporting the contention that they are not real savannas. Nevertheless, due to the dynamism of compositional forms, which often sees savannas becoming thickets and vice versa, "in the absence of better understanding of the ecology of thickets, we treat them as a class of savannas rather than as miniature dry forests" [ 11 ]. This position is supported by several authors, who include "thicket and shrub" in the vegetation types classified as savanna, and note that thickets, which may be found in "a great diversity of environments, close to the rainforest as well as near the desert edge", are common aspects of coastal savannas [ 12,13$]$.

*Corresponding author: Michael O'Neal Campbell*, Environmental Scientist, Lake head University, Ontario, Canada, Tel: 250220 3434; E-mail: ecol55@hotmail.com

Received November 11, 2013; Accepted November 26, 2013; Published December 02, 2013

Citation: Campbell MON (2013) Biodiversity and the African Savanna: Problems of Definition and Interpretation. J Biodivers Endanger Species 1: 116 doi: 10.4172/2332-2543.1000116

Copyright: ( 2013 Campbell MON. This is an open-access article distributed under the terms of the Creative Commons Attribution License, which permits unrestricted use, distribution, and reproduction in any medium, provided the original author and source are credited. 
Savannas cover about half the African continent and one fifth of the land surface of the world [11]. Despite the fact that savannas cover a greater area of the earth's surface than tropical moist forests, the latter areas receive more attention in the western media and research traditions, a situation that must be rectified [14-16]. Savanna landscapes vary in the relative proportions of trees, shrubs and grasses, and such variability is due to both human and natural elements $[17,18]$ There is a broad range of climatic types within which savanna may develop, with average annual rainfall varying from 2000 to 250 millimeters, these being intermediate between moist forest and desert $[6,19,20]$.

\section{Theoretical Developments}

The study of the paradigms that have been developed to describe and analyze the complex relationships embedded in savanna ecology and phytogeographical dynamics at the savanna/forest boundary is "an immense subject" [21]. The theoretical paradoxes and controversies that have been generated by such conflicts within the multidisciplinary literature on savanna vegetation have been amplified by the multiplicity of contexts and compositional forms that characterize this biome [1617]. Nevertheless, further attempts to understand these contexts are worthwhile, because "the majority of people in the tropics, over onefifth of the world's population, live in savannas" and such studies may contribute to "the long term survival of so many people, who are already threatened with landscape degradation, drought, famine and disease" [ 19 l $]$ ]. Ecological theories must be adapted to explain and analyze contexts that exhibit the co-dominance of grasses and trees, and the socio-environmental dynamics that influence such ratios $[22,23]$ An intriguing possibility for the critical mind is the creation, through research, of incisive knowledge on and around perceived theoretical gaps and inconsistencies, the better to explain at various spatial scales, environmental change [19,24-26]. Useful tools in such endeavors are ground ecological surveys, aerial photographs, maps and satellite imagery $[14,19,20,27-30]$. Because of these complexities, it has become an intriguing question to construct theoretical models to describe, analyze and possibly enable the management of savanna contexts [31-33] This is of "intrinsic, heuristic value", but a balance must be struck between general models and contextual variations $[9,34]$. To test these models there must also be field studies $[15,19,35]$. The complexity and heterogeneity of savanna vegetation has created several theoretical controversies, largely due to the prevalence and dominance of structured paradigms that are insufficiently sensitive to context and value perceptions [11]. A key issue concerns the tendency to see all savannas as the products of forest modification and degradation, although their complexity and spatial prevalence in variable climatic contexts merits an examination of their uniqueness from a broader and more objective perspective. It must be recognized that "the 'core' savannas are ecosystems in their own right..." not "simply secondary forms derived from forest communities", and there is need for research into their "peculiar ecologies and ethno ecologies" [19, 36].

This is an important point, as there is a "common misconception is that savannas are transitional between grasslands and forests" [ 11 ], even though pure grasslands are rare in, for example, Africa and trees and shrubs commonly exist in dynamic disequilibrium with grasses. There is also a difficultly in distinguishing "tree" savanna from "shrub" savanna, as there is no clear distinction between trees and shrubs.

Trees may be defined as plants with a distinct bole or trunk exceeding seven to eight meters in height, while shrubs may be shorter, low branched with short, "contorted" stems, although such distinctions may be "unrealistic", as under varying conditions, tree/shrub definitions may overlap [11]. An important point in that does not mention is the role played by firewood cutting in the creation of low stemmed and branched trees that pass for shrubs: a good example being the 'stunted' neem trees (Azadirachta indica) that dominate certain 'thicket' contexts of the coastal savanna of Ghana [22, 29].

The abiotic factors are also open to misinterpretation [15, 37]. In terms of fire occurrence for example, fire can be taken to be a natural aspect of the dynamism of the ecosystem rather than an unusual occurrence that converts forest into grassland [38]. Therefore, the "association between fire and savannas is as old as savannas themselves, since it follows from their climate and fuel characteristics" and to "argue from this observation that savannas are merely arrested forests is analogous to saying that if they received more water they would be forests" [11].

The positing of "ethno-ecologies" [19] as a vital area for research inquiry highlights the key role played by social dynamics in the promotion of environmental disequilibrium and complexity. Supporting authors, all of whom argued for holism rather than reductionism for further socio-environmental understanding . [37-44]. This is also relevant to the position that paradigmatic and cultural perspectives, within larger knowledge systems, have created polarized viewpoints on environmental phenomena, Several authors [16,19,37,43-48] offer the example of fire, which may be viewed as a negative factor from the forest ecology perspective (because it causes deforestation), yet positively by those who study savannas (especially savanna ecologists) and the farmers, herders and other rural actors whose livelihoods are enabled by centuries of adaptation to savanna contexts.

The conclusions to be drawn from this ecological debate reflect recent developments in ecological and possibly sociological research, in particular the dynamic structuration perspective in the social sciences $[49,50]$ which rejects the deterministic linearity of social structural analysis. Here, complex social action is related to ecological change, in a dynamic relationship, resulting in continual savanna change. In the context of socio-environmental relations in the African savanna, such approaches view cultures as being in constant, largely non-linear transition, both in terms of their co evolutionary relationships with the environment [51-53] and with regard to the flexible fabric of society, emphasizing the dynamics of social action within a constraining and enabling relationship. The intrusion of disequilibrium theory into the social sciences has spawned new topics and sub-disciplines [38], examples being co evolution [54, 55] political ecology [56-63] human ecology [64] cultural ecology [65-66] the cultural ecology of development [67] and environmental sociology [44]

\section{Hierarchy Theory and the PAM/PAN Plane}

Analyzing the basic issues around which further theoretical discourse may be developed, it is argued that "savanna form is governed by the intricate interplay of five key ecological factors, namely Plant Available Moisture (PAM), Plant Available Nutrients (PAN), fire, herbivore and major anthropogenic events" [ 19 ]. These may be also expressed water, nutrients, fire, herbivore and human activities [11]. These are a "hierarchy of determinants" because it is possible to place these factors in a hierarchy in terms of significance and causative linkages. One argument is that PAM and PAN are the "initial determinants" with fire, herbivore and anthropogenic influences being classified as "secondary modifiers" of the primary production resulting from PAM and PAN [19].

This perspective in ecological theory led to the postulation of 
the 'PAM/PAN' plane which assumed that PAM and PAN were key determinants, and hence, the properties of savanna systems "be located within a plane defined by axes of PAM and PAN", with location specific variations being used for classifying savannas [19]. Experience suggests a contrary view: PAM and PAN are not equal, "PAN is nearly always constrained by PAM" and in many instances PAN exercises no significant control at all, so that "PAN is thus lower in the hierarchy of determinants than PAM" [19]. The importance of moisture as a contributory factor has been strongly supported in the literature $[2,9$, $21,34,35,68]$.

Other authors modeling savanna dynamics differ in the relative importance they attach to the hierarchy of fire, herbivore and historical, anthropogenic factors Werner PA et al. $[9,22,34,68]$ places human influence at the third level of the hierarchy, equal with fire and herbivores, but [19] produces a model that place such issues at the top of the hierarchy. Each of the factors at the different levels of the hierarchy is termed as 'holons' or subsystems that interact with other subsystems at the same level of the hierarchy. Holons also affect those lower down in the hierarchy. Therefore, if human factors are placed at the top, it means that people affect fire and herbivory, which also affect PAM and PAN. PAM may be ranked above PAN because moisture (from rainfall, ground water and even irrigation) affects nutrients more than the other way around.

The application of this hierarchical model to spatial ecological analysis follows the "four basic scales" of savanna studies (progressively from small to larger, these are patch, catena, landscape and region) $[16,19,29]$. In small areas species composition is more important, while at the landscape level it is broad vegetation physiognomy. Human influences and PAM (largely affected by climate) are important at all levels (patch, catena, landscape and regional) while fire and herbivory are more relevant to the first three, because of contextual variation over regional scales. PAN, by contrast, is more relevant at the patch and catena spatial contexts, as soils vary greatly at such levels. Holons or subsystems may be further deconstructed into a more detailed hierarchical analysis. For example, PAM is variable at the catena level, in terms of ground water and topographical factors, evapotranspiration and infiltration rates. These variables must be contextualized at different spatial scales, and the perception of such scale linkages will be helpful in understanding environmental change [19, 39]. While the approach is useful, the research foci of individual researchers may hamper its applicability. The emphases of some biologists at the patch scale constrains the development of research at larger spatial scales [19, 69]. Subjectivity of appraisal is an overall problem, as each investigator stresses the variables that are of individual interest [70].

An example concerns the difference between the perspectives of ecologists and biogeographers [70-79]. The emphases of ecology are largely micro scale issues such as plant reproduction [77] plant/animal relationships [76] competition between organisms [64], plant structure and function [78] and ecosystem functional interactions [78]. Many biogeographical studies [71-79] emphasize the broader issues of floral history [72], vegetation structure and form [73], plant diversity and endemism [72] and time regimes [75].

Over-generalizations, subjective definitions of scale and insufficiently detailed research are also serious problems. This isn partly due to the lack of empirical data from censuses over the long term $[15,16,37,68,80-82]$. Studies at all the scales will be necessary before the linkages in the hierarchy of determinants can be used to analyze environmental change, examining processes that influence phytogeographical form upwards from the patch to the global scale and down again.

\section{The Equilibrium/Disequilibrium Debate and the African Savanna}

The relationship between forest and savanna vegetation, and the determination of the extent to which one vegetation form has replaced the other is a contested issue in the literature. The cited references $[2,3,14,19,24]$ are very relevant because the extent to which forest and savanna vegetation replace each other, and the relative roles of human factors, fire (natural and human induced), herbivores, plant available moisture (or PAM, usually expressed as rainfall, ground water and sometimes, relative humidity) and Plant Available Nutrients (PAN) are given varying prominence [83]. Note that there is not even consensus on the actual extent of annual global deforestation: estimates vary from 33,000 to $201,000 \mathrm{~km} 2$.

Some models offer strong predictions of global biodiversity change, without considering the possibility of unpredictable events $[37,84,85]$. This may result in flawed perceptions of environmental change. For example, dry season severity is a principal factor influencing the development of savanna vegetation, and this may be complemented by farming, fires and edaphic factors to reduce the density and extent of tree stands $[15,18,21]$. The actual effects of farming, firewood cutting, timber extraction and construction on the environment are disputed [86]. Argues that the environmental impacts of socio-environmental relations depend on the "specific historical and geographic conditions which obtain in a given situation". Yet, arguments concerning the factors involved in the relationships between savannas and forests (and sometimes deserts) have become underlying cores of general and polarized theoretical perspectives.

A fundamental dispute within savanna ecology concerns the rise of paradigms that emphasize non-linear disequilibrium models (this paradigm may also be termed the "new ecology" [38] as counterpoints to the classical position of linear, mechanistic change exemplified by 'natural' vegetation [87], climatic climaxes, succession and humannature separation $[2,15,37,88]$. The equilibrium position favored ecosystem theory, mechanistic succession and vegetation climaxes, because there was an inherent assumption in the power of generalization and scientific universalism $[44,80,82,89-94$, $]$

The "non equilibrium hypothesis" has developed slowly over the years $[2,95-96,97,98]$. These positions may be termed disequilibrium analyses, because they emphasize the dynamics of interrelationships within complex and unpredictable socio- environmental contexts [11, $14,24,88,99]$. "Chaotic fluctuations" in socio-environmental contexts are emphasized [38], challenging the equilibrium position of classical ecology (as argued for example by [94,100-101].

One example is are the studies of savanna soils in Zimbabwe, where "the way environmental change is conceptualized is crucial", and suggests a need for further studies that emphasize "non-linear, multidirectional, punctuated... dynamic and non-equilibrium possibilities for processes of transformation", and an understanding of ecosystem change "in more historical terms" [ 37 ]. Field work is thus important. Intrinsic in this approach is the recognition that changed environments "do not necessarily revert to their previous state when the occurrence of the disturbance ceases $[2,35,38,68]$. To this may be added the caution that the previous state may not be known. It is thus necessary to investigate the "site histories" of particular contexts [38]. The incorporation of social dynamics will complement this, enhancing a perspective that sees the environment as influencing and being influenced by people $[37,52,85,88]$ and often subject to "multiple interpretations" and "various forms of uncertainty and indeterminacy" [37]. 
The opposing equilibrium paradigm for biosphere phenomena is "hindered by a number of formidable difficulties", a problem which is due to the "large number of variables and poorly known parameters blurring some fundamental underlying regularities" [ 102 ]. It is also fundamentally flawed, because "it overlooks the possibility that both the biota and our physical environment are dynamic systems generating complexity as a result of the very nature of the laws to which they are subjected". A further problem occurs because knowledge derived from certain contexts, such as the temperate grasslands or tropical forests, is not adequate for the explanation of the dynamics of savanna change, which may include "bush encroachment and multispecies herbivory" [11] necessitating a broad perspective $[16,103]$.

Descriptions of forest/savanna boundaries as lines are often oversimplifications. Such complex disequilibrium or "bifurcation and chaos" of the "geosphere- biosphere system is, to a large extent, an intrinsic property, rather than a manifestation of incomplete knowledge or of the presence of a large number of variables and parameters" [68]. Crucially, "unpredictable abiotic events" are part of "healthy ecosystem behavior" [15].

The fundamental characterization of natural (and sometimes socio-environmental) systems within the equilibrium paradigm is that of linearity, end points and nature/society separation $[21,36,85,98]$ and biogeographical generalization of biomes [105]. Examples are 'cause and effect' perspectives, sequential change and mechanistic succession, end states or climaxes. With predictable progress within an ecosystem being charted by scientific investigation, new and little understood 'interruptions' such as environmental catastrophes or human 'intervention' are posited as anomalous externalities which temporarily induce disequilibrium, a situation which time corrects as the system slowly recovers its previous equilibrium, or which may permanently degrade it. This perspective, related to Newtonian physics, propounded the notion of "deterministic dynamics" and the essence of as "a few simple laws" Sullivan S et al. [15,106] criticizes this paradigm, and points out that "the crucial point about thermodynamic systems is that any deflection from normal behavior or equilibrium is seen as a random fluctuation or noise rather than as an integral part of the system".

The view of the natural system being in equilibrium is not limited to the 'scientific' community, but is prevalent in political and wider public circles, leading to linear models of development $[15,37,107]$ which may be described as the Dominant Development Paradigm. There is evidence that "until recently, for the public and the vast majority of scientists themselves, the world was viewed as a harmonious system that was in a state of equilibrium or near it" [106]. Common themes for this perception were the "balance of nature", an "ideal state of nature" and nature's "proper functioning". The institutionalization of this paradigm within scientific, and even economic, circles served to legitimize scientific and socio- economic models, both nationally and globally [15]. The term "balance of nature" was described as a "cultural metaphor" which is "rooted in western culture" [ 88]. Within development policy it is "still very much alive and well in some quarters" and is related to an "objectivist" approach to environmental problems [44].

\section{Case Studies of the African Savanna}

Relating these issues to the African savanna, several studies have revealed conflicts between established, 'institutionalized' views of environmental 'degradation' and the evidence revealed in satellite imagery, aerial photographs and/or field research. This has been reflected in new surveys, which reveal that African savanna landscapes are "non equilibrium or multistate systems which tend to flow from one state to another" and that the advance of deserts does not follow the simplistic sequence frequently portrayed in the literature [2,35]. Thus, a key issue for theory concerns the prevalence of equilibrium and linear thinking as established doctrine and the discovery of new evidence postulating a disequilibrium perspective [11].

More recent studies of African environments that test these hypotheses tend to utilize four main sets of data: aerial photographs and/or satellite imagery, ground surveys, social research and historical data. In particular, aerial photographs are favored because they give a more objective indication of change than policy discourses or ground surveys of different times [51,52] Examples of such studies are discussed below.

The findings of a study conducted in Namibia suggest that the extensive, environmental catastrophes enumerated in many studies do not exist, and such opinions are based on personal beliefs "rather than on the weight of empirically tested evidence" [ 15 ]. These results illustrate the position that "belief in equilibrium theory amounts to verification of a paradigm due to faith in that paradigm" [97]. In Namibia, established 'wisdom' perceived the environment as a human constructed disaster. Vegetation was devastated by overgrazing [108], there were extensive counter effects on the livestock industry [109] and an eventual "collapse" was envisaged Sullivan S et al. $[15,110]$ study showed contrary evidence: climatic variability allowed grassland regeneration, questioning both the negative assessments previously established and also the validity In another study in Guinea, [51] there was evidence of a "vegetation history that sharply contradicts the deforestation analysis and thus exposes the assumptions in its supporting social narrative; assumptions stabilized within regional narratives based more on western imagination than African realities". The environmental context examined in this case was the forest margin zone in Guinea. Embedded in this study are refutations of the position that local communities have declined in their ability to maintain forest vegetation and other environmental resources, and that a forested past was thus analogous with a "moral" past. The "deforestation narrative" is a powerful treatise on how structural, socio-economic change is believed to have contributed to deforestation and how this has caused socio- environmental externalities. The "counter narrative" explores aerial photographs which provide "incontrovertible evidence" of increased or stable forest areas between 1952 and 1994. The data are supported by the testimony of local respondents, colonial records and oral history.

This study on Guinea refuted many issues of the established narratives, and supported the disequilibrium perspective in phytogeographical change [51]. In this study, in some contexts, "local land use can be vegetation enriching as well as degrading" and it "can (and often does) serve to increase the proportion of useful vegetation forms and species in the landscape, according to prevailing local values and productivity criteria" [51]. This may be exemplified by maintenance or actual increases in tree stands through planting of "forest initiating trees" ("forest islands" may expand around villages), enrichment of soil through dumping of household waste and gardening, the cutting of flammable grasses, and seed source protection [51-52].

The dynamism of socio-environmental relationships, within the larger issue of savanna disequilibrium, was also revealed to be based on the sum of a "diffuse set of relations, a constellation rather than a structure", relegating to secondary importance the overly structuralist perspective emphasizing sociocultural organizations and village leaders [51]. There was evidence of complex interactions at individual actor, 
household, and compound levels (managing hunting and farming fires which prevent larger fires later, and the planting of tree crop plantations) within integrated relationships, that "the combined effect on resource enrichment is greater than the sum of their parts" influencing the form of phytogeographical disequilibrium. This points to a structuration perspective, as although these activities are decided at the actor level, through the larger structures reinforced by local people, village leaders do exert a certain amount of influence over burning, cattle tethering dates, the co-ordination of rotations and negotiation with pastoralist settlers.

The relationship between deforestation and population increase, frequently portrayed as linear and positively correlated, was also revealed to be dynamic, complex and in some cases negatively correlated. In the Ziama area of Guinea, populations have not increased, as commonly believed, while new research challenges the deforestation narrative which holds that the forests of Ziama are relics of larger stands, degraded under population pressure and socio-economic change, revealing forest expansion [51].

The assumption that there was original "African vegetation" that fell within a definite climax which, under unchanging conditions, was subjected to degrading human activities was not substantiated in this study. Also refuted was the belief that traditional "African society" was in the past "harmoniously integrated with 'natural' vegetation", and was "sedentary and subsistence oriented with an anti-commercial sentiment", a situation that is believed to have changed with socioeconomic structural change, described with temporal and linear analysis [51].

In terms of practical application, the disequilibrium counter narrative may have the potential to develop and contribute to "different and more appropriate guidelines for policy" [ 51 ]. This approach exhibits greater sensitivity to local issues and dialogues with actors conducted in a participatory and horizontal, rather than vertical framework and rejects the existence of a "baseline link between society and vegetation form", a position that has justified corrective development interventions to rectify deviations from a "lost social order" [51].

In another study in the Machakos Reserve of Kenya land degradation, termed the "Machakos problem" was believed to be caused by "environmental misuse" population growth, the expansion of dry land farming and livestock rearing, with resultant famine and forest to badland trajectorie [112]. Examination of photographic evidence from 1937 and 1991, however, shows the opposite: badlands have been replaced by farmlands, "erosion scars" have been reduced or have vanished, tree numbers have increased, the vegetation on grazing lands is virtually unchanged, and all this has taken place in the face of a fivefold population increase in the area between 1937 and 1991. Even technology appeared to be developed and made more effective by population growth that broadened socio-environmental relations. Increased population meant increased food needs, labor supply, idea creation and development of infrastructure. People struggled successfully with the environment for sustenance $[112,114]$.

The merit of these case studies $[15,51,52,112,113,115]$ stems largely from their contribution to the argument that it is parochial to take a mechanistic viewpoint on socio-environmental analysis. However, while these studies happened to be in areas where evidence from aerial photographs and local surveys contradicted established discourse on deforestation, this does not mean that there is no deforestation in Africa. Some studies [51,52,115] too often generalize about their findings by using the term "West African" or "African" as if different contexts all support the same counter narrative. The innumerable contexts of the African continent offer ample scope for different forms of phytogeographical change, including sequential deforestation. It must be noted that "the pendulum can swing too far in debunking orthodoxy" [85]. Therefore, it is necessary to take a final reflexive look at the results, thus not to over generalize the counter narrative $[51,52,115]$.

For example, in the Guinea savanna of the Upper West region of Ghana [116], similar research tools as those in the cited references were used [51,52,115] (Land Satellite Multi-Spectral Scanner (MSS) images from 1972 and 1989, local ground surveys, and semistructured interviews), but the conclusion showed not reforestation, but deforestation, with the most significant changes being around the settlements of Busie, Wa and Han, where grain cultivation and animal rearing were intensive. Therefore, the deforestation narrative was found to accurate, with generalized substantial tree losses, and only limited regeneration in local areas.

In another study in the coastal savanna of Ghana [117] used aerial photographs, quadrats, social surveys and archival data, and also found deforestation. The Pinkwae area of the coastal savanna of Ghana also contains fetish groves however, which comprise 1.2 square kilometers of forest. This was the site of a battle between the people of Katamanso and the Ashantis in 1826. It is believed that the spirits of the ancestors who died in the battle live in the fetish groves with the god Afiye, the deity who was believed to have helped rout the Ashantis. Thus, within the fetish grove, no farming is practiced and trees prosper. However, outside the fetish groves, farmland has replaced tree stands [117-118].

In a study utilizing remotely sensed data and field data collection covering eight countries (Ghana, Congo, Cote de Ivoire, Ethiopia, Mali, Senegal, South Africa and Zaire), the results showed substantial deforestation had occurred in several areas, with cases of drier savanna woodland showing signs of 'severe degradation', being replaced by farm/shrub/grass mosaics. Farming and firewood cutting were blamed for the substantial tree losses, but the boundaries of the forests and savannas were argued to be dynamic, due to the unpredictable human and climatic influences [18]. Another study utilized remote sensing, which revealed tree losses in the savanna woodland of Guinea, Sierra Leone and Cote de Ivoire. By the "end of the dry season, however, a more or less continuous burned belt 100-200 kilometers wide is found in the southern part of the savanna range" [ 1 ].

A study in the Highlands of Tigray in Ethiopia using remote sensing also found substantial vegetation losses, which was posited as the factor behind increased soil erosion [119]. Another study in the hinterland of Niger [111] used satellite imagery and found deforestation over a period of twenty years, largely as a result of population increase, over exploitation of cropland and overgrazing of rangelands, causing pronounced erosion. In the Cross River area of Nigeria, a similar result was found [112] Based on maps, aerial photographs, Rapid Rural Appraisal, questionnaires, archival and documentary sources and informal interviews) the study revealed substantial deforestation. In this study, farming is posited as the main factor behind declining tree stands.

Nevertheless, such contrasting research results do not negate the disequilibrium analysis, but rather strengthen it. Evidence from aerial photographs may arguably represent "incontrovertible evidence") of different forms of (general) phytogeographical change, viewed from the vantage point of wider processes of socio- environmental interaction [51]. This underscores the dynamic and heterogeneous nature of the 
Citation: Campbell MON (2013) Biodiversity and the African Savanna: Problems of Definition and Interpretation. J Biodivers Endanger Species 1: 116. doi: $10.4172 / 2332-2543.1000116$

West African savanna. Further, neither deforestation nor reforestation represent permanent trajectories, but may be subject to change over time [37]. Therefore, the strength of the disequilibrium position rests in its ability to survive different research conclusions, because these variations are further evidence of disequilibrium and heterogeneity $[15,38]$.

The foregoing debates concerning ecological change thus tend to refute the notions of linear succession towards a single vegetation climax. What they seem to suggest is a scenario of more or less permanent multi-directional transition provoked by complex sets of variables "rather than by trends in (a) particular variable (s)" [51]. Such change may be divergent, as the removal of a factor of disturbance may not return a formation to resembling its original form $[2,15,66,120]$. Thus, the contingent nature of vegetation form may makes investigation of a region's "archetypal vegetation" redundant [51].

\section{Conclusions}

This article has examined the main theoretical arguments and ecological methods that have been developed to analyze the structure of the African savanna, contrasting the more recent disequilibrium ecology paradigm, which sees the savanna as in continual flux rather than stable equilibrium, with the older equilibrium paradigm, and examined the relations with the social sciences and the evidence for these paradigms. The results hint that the complexity of the African savanna justifies the integrated research methods, which provide a useful basis for the advancement of biodiversity studies. The citations in this article are not intended to give an exhaustive list of problems and solutions, but for illustrative possibilities, potential new monitoring techniques, and expansion of current methods. Arguably, the multiplicity of theoretical studies that have emerged to enable such syntheses testifies to the difficulty of the construction of adequate integrative studies. Critical experimentation using the methods described utilize (aerial photographs and/or satellite imagery, ground surveys, social research and historical data).appears to have high potential and these may provide a good testing ground, with possibilities for generic application elsewhere. If such integrated research is to be truly effective in the more accurate assessment of savanna status and change, measurable parameters must be identified, within the multiple strands of ecological and social relations, in multiple real or hypothesized scenarios, with multiple techniques, including images, statistics, qualitative social measurements and frameworks of integration.

\section{References}

1. Medina E, Huber O (1994) The role of biodiversity in the functioning of savanna ecosystems. In; Biodiversity and Global Change. Editors Solbrig OT, Van Emden HM, Oordt PGWJ. CAB International, Wallingford 141-160.

2. Solbrig OT (1993) Ecological constraints to savanna land use. In; The World's Savannas: Economic Driving Forces, Ecological Constraints and Policy Options for Sustainable Land Use. Young MD, Solbrig. The Pantheon Publishing Group, Paris 21-47.

3. Mistry J (2000) World Savanna: Ecology and Human Use. Prentice Hall, Harlow.

4. Campbell MO (2005) The ecological and social context of mammal hunting in the coastal savanna of Ghana. Geoforum 36: 667-680.

5. Parr CL, Andersen AN (2006) Patch mosaic burning for biodiversity conservation: A critique of the pyrodiversity paradigm. Conserv Biol 20: 16101619.

6. Harris DR (1980) Human Ecology in Savanna Environments. Academic Press London.

7. Scholes RJ, Walker BH (2004) An African Savanna: Synthesis of the Nylsvley Study. Cambridge University Press, Cambridge.
8. Frost PGH, Menaut JC, Walker BH, Medina E, Solbrig OT, et al. (1986) Responses of savannas to stress and disturbance. In; An African Savanna: Synthesis of the Nylsvley Study. Editors Scholes RJ, Walker BH. Cambridge University Press, Cambridge 2-10.

9. Werner PA (1990) Ecological determinants of savannas: abiotic and biotic. Biogeogr 17: 401-402.

10. Menaut JC, Gignoux J, Prado C, Clobert J (1990) Tree community dynamics in a humid savanna of the Cote de Ivoire: modelling the effects of fire and competition with grass and neighbours. Journal of Biogeography 17: 471-481.

11. Scholes RJ, Walker BH (1993) An African savanna: synthesis of the Nylsvley study (Cambridge Studies in Applied Ecology and Resource Management). Cambridge University Press, Cambridge.

12. Cole MM (1986) The Savannas, Biogeography and Geobotany. Academic Press, London.

13. Menaut JC (1983) The vegetation of African savannas. In; Tropical Savannas. Editors Boulrliere F. Elsevier Scientific Publishing Company, Amsterdam.

14. Werner PA, Walker BH, Stott PA (1991) Introduction. J Biogeogr 17: 343-344.

15. Sullivan $S$ (1996) Towards a non-equilibrium ecology : perspectives from an arid land. J Biogeogr 23: 1-5.

16. Campbell MO (2013) Biogeography, Environmental History and Sustainability in Coastal Ghana. Novapublishers, New York.

17. Defries RS, Rudel T, Uriarte M, Hansen M (2010) Deforestation driven by urban population growth and agricultural trade in the twenty-first century. Nature Geoscience 3: 178-181.

18. Miller GT, Hackett D (2010) Living in the Environment. 2nd Edn Nelson Education, Toronto.

19. Stott PA (1994) Savanna landscapes and global environmental change. In; The Changing Global Environment. Roberts N, Basil Blackwell Limited, Cambridge, UK.

20. Bucini G, Lambin EF (2002) Fire impacts on vegetation in Central Africa: A remote sensing - based statistical analysis. Appl Geogr 22: 27-48.

21. Hopkins B (1992) Ecological processes at the forest savanna boundary. In Nature and Dynamics of Forest-Savanna Boundaries. Editors Furley PA Proctor J, Ratter JA. Chapman and Hall, London 21-33.

22. Elliott JA, Campbell M (2002) The environmental imprints and complexes of social dynamics in rural Africa: cases from Zimbabwe and Ghana. Geoforum 33: $221-237$

23. Meyer KM, Wiegand K, Ward D, Moustakas A (2007) The rhythm of savanna patch dynamics. J Ecol 95: 1306-1315.

24. Solbrig OT (1990) Savanna Modeling for Global Change. Biology International, Special Issues 24: 1-47.

25. Sankaran M, Ratman J, Hanan NP (2004) Tree-grass coexistence in savannas revisited-Insights from an examination of assumptions and mechanisms invoked in existing models. Ecological Letters 7:480-490.

26. Sankaran, M, Hanan, NP, Scholes, RJ, Ratman, J, Augustine DJ, et al. (2005) Determinants of Woody Cover in African Savannas. Nature 438: 846-849.

27. Kaufman YJ, Setzer A, Justice C, Tucker CJ, Pereira MC, et al. (1990) Remote sensing of biomass burning in the tropics. In; Fire on the Tropical Biota. Editors Goldhammer JG. Springer Verlag, Berlin 371-399.

28. Furley PA, Proctor J, Ratter JA (1992) Nature and Dynamics of Forest-Savanna Boundaries. Chapman and Hall, London.

29. Campbell MO (1998) Interactions between Biogeography and Rural Livelihoods in the Coastal Savanna of Ghana. PhD Thesis, University of London.

30. Verlinden A, Laamanen R (2006) Long term fire scar monitoring with remote sensing in Northern Namibia: relations between fire frequency, rainfall, land cover, fire management and trees. Environ Monit Assess 112: 231-253.

31. Duvall CS (2007) Human settlement and baobab distribution in south-western Mali. J Biogeogr 34: 1947-1961.

32. Duvall CS (2011) Biocomplexity from the ground up: Vegetation patterns in West African savanna landscape. Ann Assoc Am Geogr 101: 497-522.

33. Siljander M (2009) Predictive fire occurence modelling to improve burned area 
Citation: Campbell MON (2013) Biodiversity and the African Savanna: Problems of Definition and Interpretation. J Biodivers Endanger Species 1: 116. doi: $10.4172 / 2332-2543.1000116$

Page 7 of 8

estimation at a regional scale: A case study in East Caprivi, Namibia. Internation Journal of Applied Earth Observation and Geo information 11: 380-393.

34. Belsky AJ (1990) Tree/grass ratios in East African savannas: a comparison of existing models. J Biogeogr 17: 483-489.

35. Scoones I, Toulmin C, Lane C (1993) Land tenure for pastoral communities. In; The Worlds Savannas: Economic Driving Forces, Ecological Constraints and Policy Options for Sustainable Land Use. Editors Young MD, Solbrig OT. Parthenon Publishing Group, Paris 49-66.

36. Goetze D, Horsch B, Porembski S (2006) Dynamics of forest - savanna mosaics in north-eastern Ivory Coast from 1954 - 2002. J Biogeogr 33: 653-664.

37. Leach M, Mearns R, Scoones I (1997) Environmental Entitlements: Framework for Understanding the Institutional Dynamics of Environmental Change. University of Sussex, Brighton.

38. Christiansen NL (1993) Fire Regimes and Ecosystem Dynamics. In; Fire in the Environment: The Ecological, Atmosphere, and Climatic Importance of Vegetation Fires. Editors Crutzen P, Goldhammer JG. John Wiley and Sons, Chichester.

39. Zimmerer KS (1994) Human Geography and the "New Ecology": The Prospect and Promise of Integration. Ann Assoc Am Geogr 84: 108-125.

40. Maass JM (1995) Conversion of dry tropical forest to pasture and agriculture. In; Seasonally Dry Tropical Forests. Editors Bullock SH, Mooney HA, Medina E. Cambridge University Press, Cambridge 399-422.

41. Ellen R, Fukui K (1996) Redefining Nature, Ecology, Culture and Domestication. Bloomsbury Academic, Oxford, U.K.

42. Sponsel LE, Headland TN, Bailey RC (1996) Tropical Deforestation: the Human Dimension. Biology and Resource Management in the Tropics Series. Colombia University Press, New York.

43. Rowe JS (1997) From Reductionism to Holism in Ecology and Deep Ecology. The Ecologist 27: 4.

44. Woodgate G, Redclift M (1998) From a 'Sociology of Nature' to Environmental Sociology: Beyond Social Construction. Environ Value 7: 3-24.

45. Forsyth T (2003) Critical Political Ecology: The Politics of Environmenta Science. Routledge, New York.

46. Govender N, Trollope WSW, Van Wilgen BW (2006) The effect of fire season, fire frequency, rainfall and management on fire intensity in savanna vegetation in South Africa. J Appl Ecol 43: 748-758.

47. Laris P, Wardell DA (2006) Good, bad or "necessary evil?" Reinterpreting the colonial burning experiments in the savanna landscapes of West Africa. Geographical Journal 172: 217-290.

48. LePage Y, Duarte O, Johnson P, Silva MNJ,Pereira JMC (2010) Seasonality of vegetation fires as modified by human action. Observing the deviation from eco-climatic fire regimes. Global Ecol Biogeogr 19: 575-588.

49. Giddens A (1979) Central Problems in Social Theory: Action, Structure, and Contradiction in Social Analysis. University of California Press, Macmillan, London

50. Giddens A (1984) The Constitution of Society: Outline of the Theory of Structuration. University of California Press, Cambridge.

51. Fairhead J, Leach M (1995) False forest history, complicit social analysis: rethinking some West African environmental narratives. World Dev 23: 1023-1035.

52. Fairhead J, Leach M (1996) Misreading the African Landscape: Society and Ecology in a Forest Savanna Mosaic. Cambridge University Press, Cambridge.

53. Hakeem SA, Vemuri SR (1997) Structural Adaption of Human Settlements to Climate for Sustainable Agriculture. J Sustain Agr 10: 63-74.

54. Norgaard RB (1984) Economic Development and Cultural Change. The University of Chicago Press, London.

55. Norgaard RB (1994) Development Betrayed: The End of Progress and a Co evolutionary Revisioning of the Future. Routledge, London.

56. Blaikie MP (1985) The Political Economy of Soil Erosion in Developing Countries. Longman Publishing Group, London.

57. Blaikie MP, Brookfield HC (1987) Land Degradation and Society. Methuen, London.

58. Redclift M (1987) Sustainable Development: Exploring the Contradictions Routledge, London.
59. Rocheleau DE (1991) Gender, Ecology, and the Science of Survival. Agriculture and Human Values 8: 156-165

60. Bryant RL (1992) Political ecology: an emerging research agenda in Third World studies. Polit Geogr 11: 12-36.

61. Woodgate GR (1992) Sustainability and the Fate of the Peasantry: the Politica Ecology of Livelihoods Systems in an Upland Agroecosystem in the Centra Highlands of Mexico. University of London.

62. Peet R, Watts M (1996) Liberation Ecologies: Environment, Development Social Movements. Routledge, London.

63. Bryant RL Bailey S (1997) Third World Political Ecology. Routledge, London.

64. Whyte AVT (1986) From hazard perception to human ecology. In; Geography, Resources and Environment Editors; Kates RW, Burton I 2: 240-271.

65. Kates RW (1987) The Human Environment: The Road Not Taken, the Road Stil Beckoning. Ann Assoc Am Geogr 77: 525-534.

66. Turner II BL (1989) The Specialist-Synthesis Approach to the Revival of Geography: The Case of Cultural Ecology. Ann Assoc Am Geogr 79: 88-100.

67. Grossman L (1981) The Cultural Ecology of Economic Development. Ann Assoc Am Geogr 71: 220-236.

68. Laris P (2011) Humanizing Savanna Biogeography: Linking Human Practices with Ecological Patterns with Ecological Patterns in a Frequently Burned Savanna of Southern Mali. Ann Assoc Am Geogr 101: 1067-1088.

69. Allan JA (1991) Global biogeography: who is Responsible? Journal of Biogeography 18: 121-122.

70. Tivy, O'Hare (1981) Human Impact on the Ecosystem. Oliver \& Boyd, Edinburgh

71. Bond WJ, Cowling RM, Richards MB (1992) Competition and coexistence. Oxford University Press, Cape Town.

72. Cowling RM Holmes PM (1992) The Ecology of Fynbos: Nutrients, Fire and Diversity. Oxford University Press, Cape Town, South Africa.

73. Cowling RM, Holmes PM, Rebelo AG (1992) Plant diversity and endemism. In; The Ecology of Fynbos: Nutrients, Fire and Diversity. Editors Cowling RM. Oxford University Press, Cape Town, South Africa

74. Deacon HJ, Jury MR, Ellis F (1992) Selective regime and time. In; The Ecology of Fynbos: Nutrients, Fire and Diversity. Editors Cowling RM. Oxford University Press, Cape Town, South Africa 6-22.

75. Johnson SD (1992) Plant animal relationships. In; The Ecology of Fynbos: Nutrients, Fire and Diversity. Editors Cowling RM. Oxford University Press Cape Town 175-205.

76. le Maitre DC, Midgley JJ (1992) Plant reproductive ecology. In; The Ecology of Fynbos: Nutrients, Fire and Diversity. Editors Cowling RM. Oxford University Press, Cape Town, South Africa 135-174.

77. Stock WD, Allsopp N (1992) Functional perspective of ecosystems. In; The Ecology of Fynbos: Nutrients, Fire and Diversity. Editors Cowling RM. Oxford University Press, Cape Town, South Africa 241-259.

78. Stock WD, Van der Heyden F, Lewis OAM (1992) Plant structure and function. In; The Ecology of Fynbos: Nutrients, Fire and Diversity. Editors Cowling RM. Oxford University Press, Cape Town, Soth Africa 226-240.

79. Pimm SL (1991) Balance of Nature: Ecological Issues in the Conservation of Species and Communities. University of Chicago Press, Chicago.

80. Edwards PJ, May RM, Webb NR (1994) Large Scale Ecology and Conservation Biology. Wiley-Blackwell Scientific Publications, U.K.

81. Burrows CJ (1990) Processes of Vegetation Change. Unwin Hyman Ltd, London.

82. Mueller-Dombois D, Goldhammer JG (1990) Fire in tropical ecosystems and global environmental change: an Introduction. In; Fire in the Tropical Biota: Ecosystem Processes and Global Challenges. Editors Goldhammer JG. Spriger Verlag, Berlin 1-10.

83. Bakkes JA Van Woerden JW, Alcamo J, Berk MM, Bol P, et al. (1997) The Future of the Global Environment: a Model-Based Analysis Supporting UNEP's First Global Environment Outlook. UNEP, Nairobi.

84. Batterbury S, Forsyth T Thompson K (1997) Environmental transformations in developing countries: Hybrid Research and Democratic Policy. The Geographical Journal 163: 126-132. 
Citation: Campbell MON (2013) Biodiversity and the African Savanna: Problems of Definition and Interpretation. J Biodivers Endanger Species 1: 116. doi: $10.4172 / 2332-2543.1000116$

Page 8 of 8

85. Cline-Cole RA Binns T (1995) Livelihood, sustainable development and indigenous forestry in dry land Nigeria. People and Environment in Africa. John Wiley and Sons, U.K

86. McNeely JA (1994) Lessons from the Past: Forests and Biodiversity. Biodivers Conserv 3: 3-20

87. Pickett STA, Parker VT, Fiedler PL (1992) The new paradigm in ecology: implications for conservation biology above the species level. In; Conservation Biology: The Theory and Practice of Nature Conservation, Preservation and Management. Editors Fiedler PL, Jain K. Chapman and Hall, NewYork 66-87.

88. Tallis JH (1991) Plant Community History: Long-term changes in plan distribution and diversity. Chapman and Hall, London.

89. Tudge C (1991) Global Ecology. Natural History Museum Publications, London.

90. Beeby A (1993) Applying Ecology. Chapman and Hall, London.

91. Simmons IG (1993) Environmental History: A Concise Introduction. Basil Blackwell Publishers, Oxford.

92. Allaby M (1994) The Concise Oxford Dictionary of Ecology. Oxford University Press, U.K.

93. Begon M, Harper JL Townsend CR (1996) Ecology: Individuals, Populations and Communities. Wiley-Blackwell, 3rd Edn, USA.

94. Holling CS (1973) Resilience and Stability of Ecological Systems. Annu Rev Ecol Syst 4: 1-24.

95. Westoby M, Walker B, Noy-Meir I (1989) Opportunistic management for rangelands not at equilibrium. J Range Manage 42: 266-274.

96. Khasa PD, Dancik BP (1997) Sustaining tropical forest biodiversity. Journal of Sustainable Forestry 5: 217-234.

97. Weins J (1984) On understanding a non-equilibrium world: myth and reality in community patterns and processes. In; Ecological Communities: Conceptual Issues and the Evidence. Editors Strong DR. Princeton University Press, New Jersy, USA.

98. Gillson L (2004) Testing non-equilibrium theories in savannas: 1400 years of vegetation change in Tsavo National Park, Kenya. Ecological Complexity 1 : 281-298.

99. Tansley AG (1935) The Use and Abuse of Vegetational Concepts and Terms. Ecology 16: 284-307.

100.Whittaker RH (1953) A Consideration of Climax Theory: The Climax as a Population and Pattern. Ecol Monogr 23: 41-78.

101. Nicolis G (1994) Dynamical systems, biological complexity and global change. In; Biodiversity and Global Change. Editors Solbrig OT, Van-Emden HM, Oordt PGWJ. CAB International, Wallingford, 21-31.

102.Longman KA, Jenik J (1992) Forest-savanna boundaries: general considerations. In; Nature and Dynamics of Forest-Savanna Boundaries. Editors Furley PA, Proctor J, Ratter JA. Chapman and Hall, London 3-20.

103. Adejuwon, JO, Adesina FA (1992) The nature and dynamics of the forestsavanna boundary in South Western Nigeria. In; Nature and Dynamics of
Forest-Savanna Boundaries. Editors Furley PA, Proctor J, Ratter. Springer London 331-352.

104. Ellery WN, Mentis MT, Scholes RJ (1992) Modelling the location of woodygrassland boundaries. In; Nature and Dynamics of Forest-Savanna Boundaries. Editors Furley PA, Proctor J, Ratter JA. Chapman and Hall, London 569-582.

105. Apffel-Marglin F, Marglin SA (1996) Decolonizing Knowledge: From Development to Dialogue. Clarendon Press, New York, USA

106. Van Warmelo NJ (1962) Notes on the Kaokoveld (South West Africa) and its people. Government Printer USA.

107. Sievers JR, Commissaris ALTM (1994) Report on Sustainable Development in the Sesfontein/Khowarib Basin. Infoscience, Windhoek (Namibia).

108. Tiffen M, Mortimore M, Gichuki F (1994) More people, less erosion: environmental recovery in Kenya. J Wiley, USA.

109. Loxton RF, Hunting (1974). The Natural Resources of Damaraland. Department of Bantu Administration and Development, Pretoria.

110. Mortimore M, Tiffen M (1995) Population and environment in time perspective the Machakos story. In; People and Environment in Africa. Editors Binns T. John Wiley and Sons, Chichester USA

111. Sullivan S (1999) The impacts of people and livestock on topographically diverse open wood-and shrub-lands in arid north-west Namibia. Global Eco Biogeogr 8: 257-277.

112. Fairhead J, Leach M (1996) Local agro-ecological management and forestsavanna transitions: the case of Kissidougou, Guinea. In; People and Environment in Africa. Editors Binns T. John Wiley and Sons Ltd, London.

113. Simon JL (1986) Theory of Population and Economic Growth. Blackwell Publishers, Oxford.

114. Nsiah-Gyabaah K (1991) Environmental Degradation and the Threat of Drought and Desertification in the Upper West Region of Ghana: a Search for Sustainable Development Solutions. PhD Thesis, University of London.

115. Lieberman D (1979) Dynamics of Forest and Thicket Vegetation on the Accra Plains, Ghana. Ph.D Thesis, University of Ghana.

116. Eweg HPA, Lammeren RV (1996) The Application of a Geographical Information at the Rehabilitation of Degraded and Degrading Areas: A Case Study in the Highlands of Tigray, Ethiopia. Agricultural University, Wageningen.

117. Spaeth HJ (1996) Land degradation in West Niger. Desertification Control Bulletin 28: 34-41.

118. Ntimoa-Baidu B (1994) Indigenous versus traditional biodiversity conservation strategies: the case of protected area systems in Ghana. In African Biodiversity: Foundation for the Future: A Framework for Integrating Biodiversity Conservation and Sustainable Development. Biodiversity Support Program, USAID, Washington.

119. Ite UE (1997) Small farmers and forest loss in Cross River National Park Nigeria. The Geographical Journal 163: 47-56.

120. Sprugel DG 1991 Disturbance Equilibrium and Environmental Variability: What is 'Natural' Vegetation in a Changing Environment? Biol Conserv 58:1-8. 